\title{
Geochemistry and Petrogenesis of Tertiary Volcanic Rocks of the Eastern Roodbar, Alborz Mountain, North of Iran
}

\author{
Zahra Shafeie ${ }^{1}$, Mohammad Ali Arian ${ }^{*}$, Shahrouz Haghnazar ${ }^{2}$, Mansour Vossoughi Abedini $^{3}$ \\ ${ }^{1}$ Department of Geology, Faculty of Science, North Tehran Branch, Islamic Azad University, Tehran, Iran \\ ${ }^{2}$ Department of Geology, Faculty of Science, Lahijan Branch, Islamic Azad University, Lahijan, Iran \\ ${ }^{3}$ Department of Geology, Faculty of Science, Science and Research Branch, Islamic Azad University, Tehran, Iran \\ Email: ${ }^{\star}$ maa1361@yahoo.com
}

How to cite this paper: Shafeie, Z., Arian, M.A., Haghnazar, S. and Abedini, M.V. (2016) Geochemistry and Petrogenesis of Tertiary Volcanic Rocks of the Eastern Roodbar, Alborz Mountain, North of Iran. Open Journal of Geology, 6, 1296-1311. http://dx.doi.org/10.4236/ojg.2016.610095

Received: August 31, 2016

Accepted: October 25, 2016

Published: October 28, 2016

Copyright $\odot 2016$ by authors and Scientific Research Publishing Inc. This work is licensed under the Creative Commons Attribution International License (CC BY 4.0).

http://creativecommons.org/licenses/by/4.0/ (c) (i) Open Access

\begin{abstract}
In the Alborz Mountains of the eastern Roodbar (north of Iran), Tertiary volcanic rocks have a variety of composition between olivine basalt, basaltic andesite, pyroxene andesite and andesite. The presence of different xenoliths and xenocrysts is among the evidence of crustal contamination of these rocks. The positive correlations of $\mathrm{CaO} / \mathrm{Al}_{2} \mathrm{O}_{3}$ vs to $\mathrm{MgO}$ and $\mathrm{Al}_{2} \mathrm{O}_{3}$ vs. $\mathrm{SiO}_{2}$ are of signs of the olivine and clinopyroxene fractionation in the variation trend of the area rocks. Positive correlations $\mathrm{K}_{2} \mathrm{O} / \mathrm{P}_{2} \mathrm{O}_{5}$ vs with $\mathrm{SiO}_{2}$ and $\mathrm{La} / \mathrm{Sm}$ vs. $\mathrm{K}_{2} \mathrm{O} / \mathrm{P}_{2} \mathrm{O}_{5}$ demonstrate contamination of magma with the continental crust. The incompatible trace element patterns and their comparison with crustal contents indicate contamination of the rocks of the area with the lower and upper continental crust. Linear trends in the variation diagram of $\mathrm{Nb} / \mathrm{Y}$ vs. Zr/Y, introduce two different source regions: a MORB source and the other continental crust for the rocks which are the genesis. The variations of $\mathrm{Y} / \mathrm{Nb}$ vs. $\mathrm{Zr} / \mathrm{Nb}$ and $\mathrm{Rb} / \mathrm{Y}$ vs. $\mathrm{Nb} / \mathrm{Y}$ reveal a crustal contamination of the magma originated from the MORB source. Geochemical studies represent that the area's rocks were derived from the $15 \%$ melting of a mantle source of MORB type with spinel facies within a continental environment, which was contaminated by varying degrees of continental crustal rocks.
\end{abstract}

\section{Keywords}

Volcanic Rocks, Tertiary, MORB Source Mantle, Crustal Contamination

\section{Introduction}

One of the most important applications of the igneous petrology is to determine the 
role of asthenosphere and lithosphere mantle in producing the melt and its relationships with geotechnical events, which has the most importance for genesis of continental and oceanic basalts of mantle composition [1]. But what should be considered in continental regions is that the primary magmas from partial melting of the mantle would be variated and modified, due to the interaction with the continental crust during ascent [2]. Thus, it should always consider the role of crustal contamination in petrogenesis of the continental within-plate magmas. Because, for example, the crustal contamination can change the geochemical properties of the continental within-plate basalts, and misleadingly show the geochemical characteristics of rocks in subduction zones [2]. Consideration of geochemical and isotopic signs of rocks allows the identification of the mantle composition and magmatic processes such as mixing, contamination and assimilation. All the continental basalts show enriched trace elements patterns. This enrichment has been generated either through metasomatic fluids penetration or explained by accepting enriched components such as crust or lithosphere by the asthenosphere and depleted mantle materials [1]. On the other hand, it can establish the relationship between the mantle source and tectonic setting of rocks: for example, the mantle type EM is in fact the lithospheric enriched mantle [3], which is possibly generated due to the subduction of crustal materials into the mantle [4]. The upper mantle wedge metasomatism has led to incompatible elements enrichment in these rocks through fluids released from the subducted plate [5]. But in the intra-continental rift regions, the asthenospheric mantle of OIB and MORB sources plays an important role in petrogenesis of basalts [2]. On the other hand, the sub-continental lithospheric mantle has been often hypothesized in the petrogenesis of basalts and both lithospheric crust and mantle are considered as the contaminant in asthenospheric magmas [6]. In this article, it is tried to investigate the characteristics of mantle source and the role of continental crust in the magmatic evolutions of Tertiary volcanic rocks through geochemical evidence and determine its relationship with the governing geodynamic setting at the time of the formation of these rocks. This could help us in better understanding of the tectonomagmatic setting of Tertiary rocks in Alborz and generally, Iran. In Figure 1, the satellite image of the studied area would be seen.

\section{Geology of the Area}

The study area is located in the East of Roodbar and Northeast of Lushan city in Gilan province, in north of Iran (Figure 2). According to division [7], this area falls in the Paleogene volcanism zone (Figure 3). The studied area is in the sheet of Jirande at a scale of $1: 100,000$ between $49^{\circ} 30^{\prime}$ and $50^{\circ} 00^{\prime}$ east longitude and $36^{\circ} 30^{\prime}$ and $37^{\circ} 00^{\prime}$ north latitude. In this part, outcrops of volcanic and pyroclastic rocks of Paleogene and especially middle Eocene age have widely extended. The Jirande sheet at a scale of 1:100,000 encompass a part of Central Alborz zone in which rock units of Paleozoic to present are exposed. The volcanic-sedimentary units of Mesozoic are mainly exposed in the northern region as thrusted sheets. But a large part of the region covered by volcano sedimentary units of Cenozoic, in particular Tertiary [8]. The units have mostly cut by dykes 


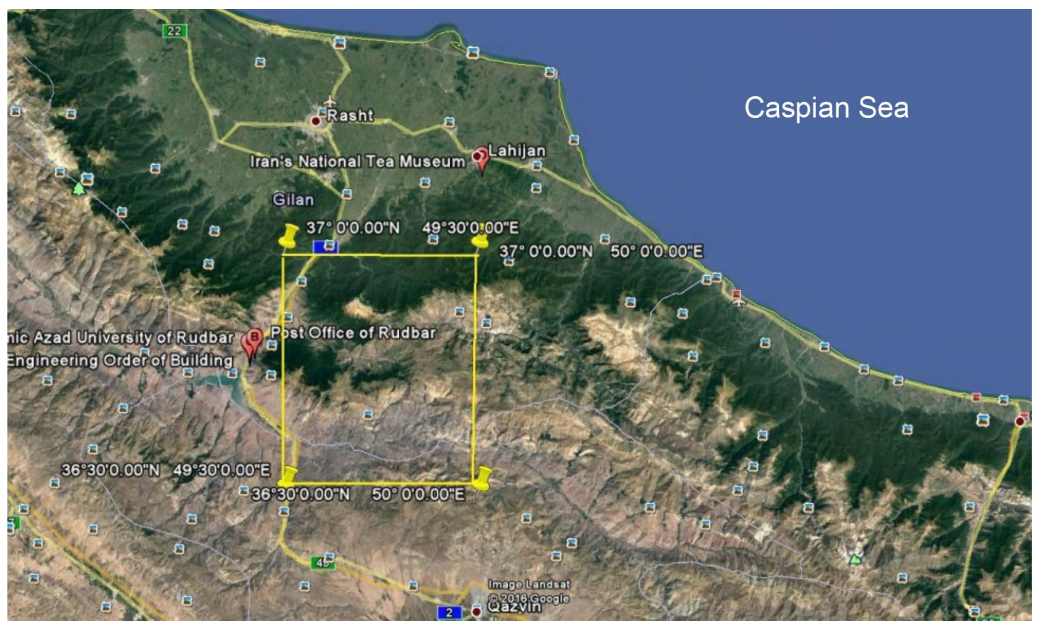

Figure 1. Satellite image of the studied area, the study area marked as a rectangle (Google Earth, 2016).

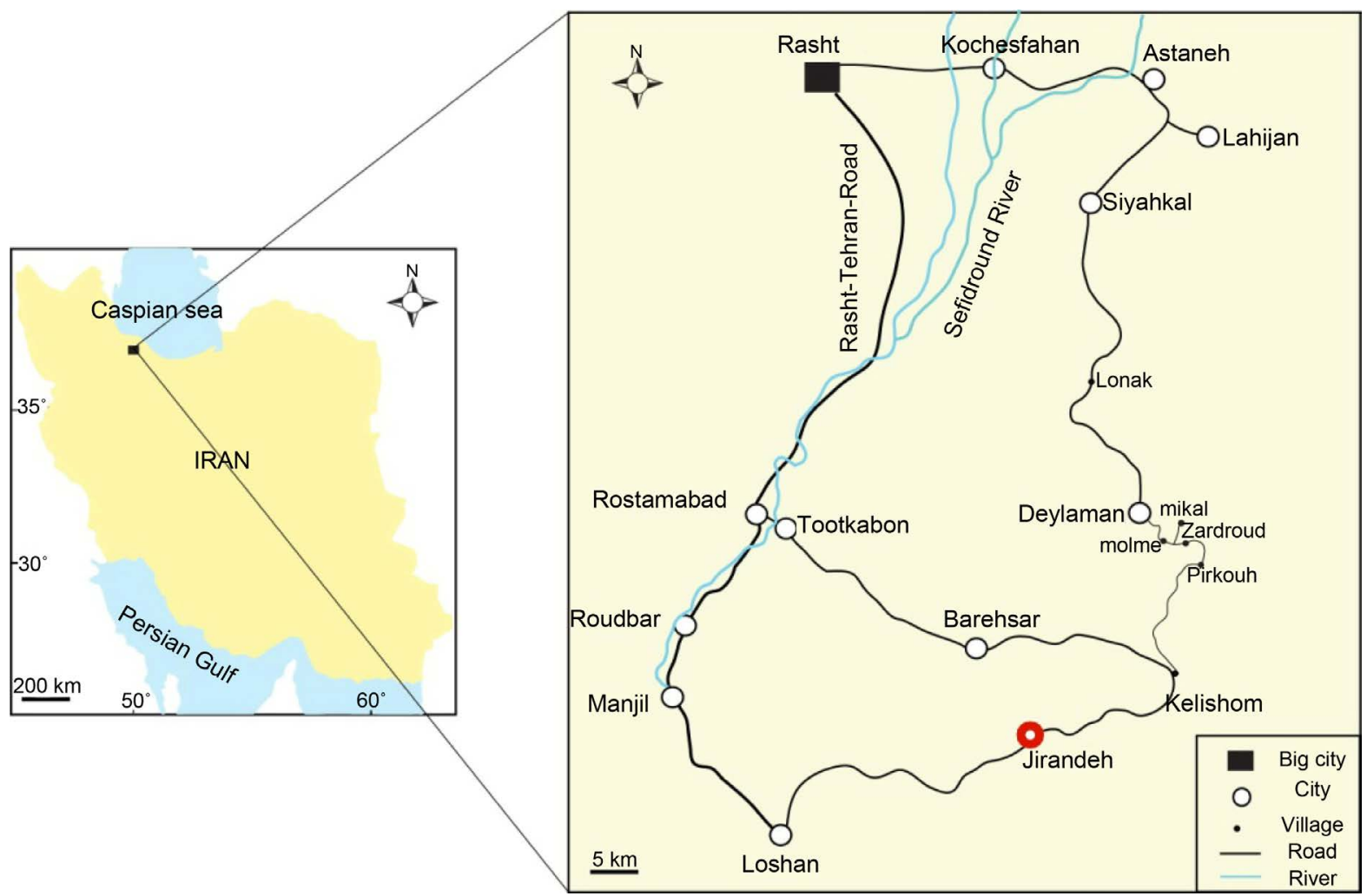

Figure 2. Access paths to the area in the east of Roodbar in Gilan province, north of Iran.

and small intrusive and subvolcanic bodies. Based on field studies, outcrops of rocks in the region from old to present include: limestone unit containing the fossil assemblages of lower to middle Eocene, olivine basalt to basaltic andesite unit with clear bedding and dark color, basic bedded pyroclasts unit comprising the collapse pyroclasts in lapilli size, heterogeneous tuffs and volcanic breccias which follow well the surface topography of olivine basalt unit. The last unit is a thick sequence consists of basaltic andesite 


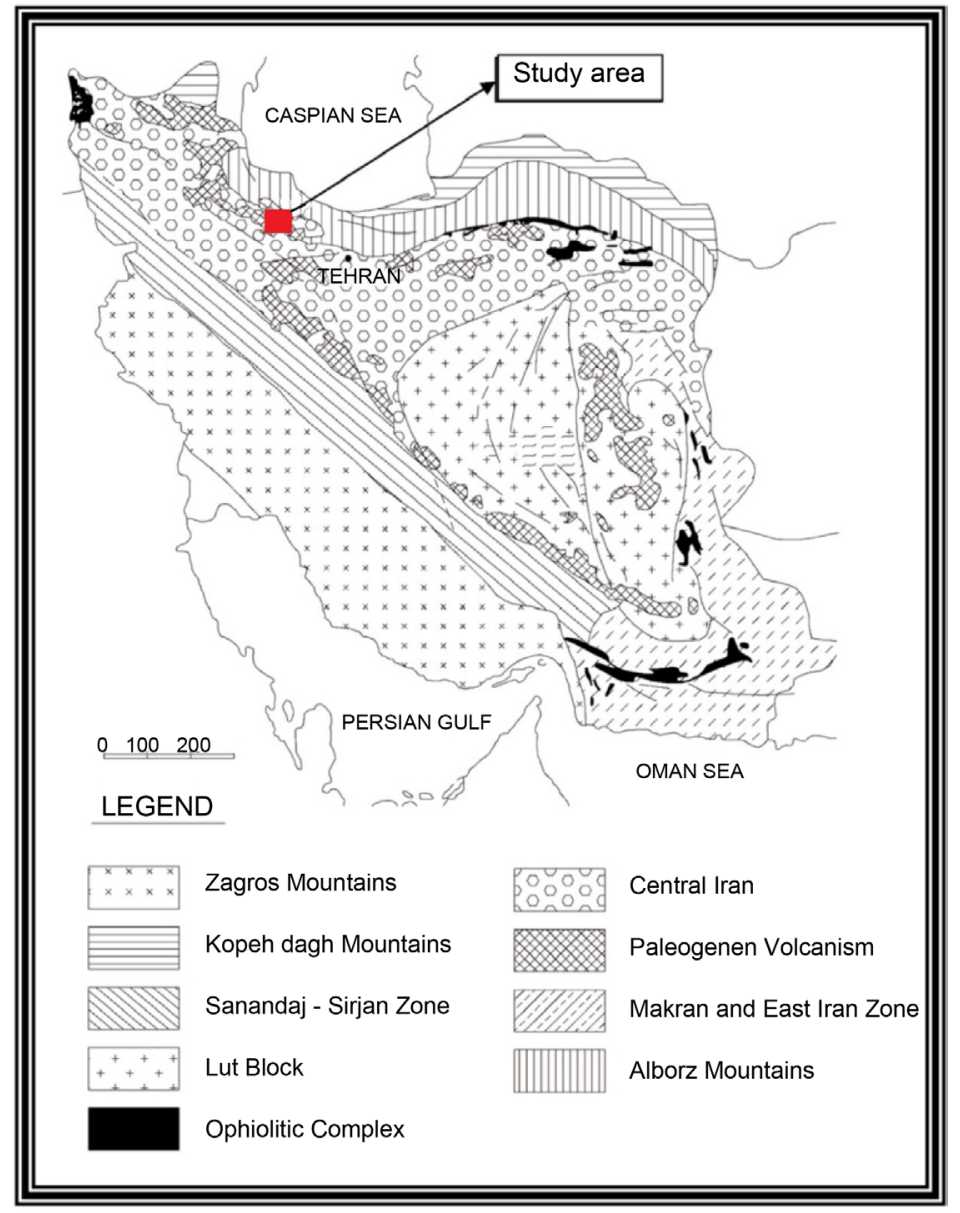

Figure 3. Structural zones division of Iran [7], the approximate location of the studied area show as quadrangle.

lavas, pyroxene andesite and andesite, which comprise the most part of the region.

\section{Methodology}

After field studies, notice to lithological varieties of the volcanic units in the region, 50 samples caught and thin sections were prepared and studied in terms of petrography using polarizing microscope. Then, among the above samples, 22 samples with the lowest weathering and most lithological variety were selected to analyze the major elements using XRF method and the trace and REE elements by ICP-MS at SGS laboratory in Toronto. In order to analyze data, the software Igpet 2007 and GCD kit are used.

\section{Discussion}

In this section, petrographic, geochemical and petrogenesis studies are explained:

Based on petrographic studies carried out on the lavas units, three rock units were distinguished: 1) olivine basalts, 2) andesitic basaltic and basaltic andesite, 3) pyroxene andesites and andesites. The first group: olivine basalt has often porphyritic texture and sometimes glomeroporphyritic. The major minerals of the rock: olivine, augite pyrox- 
ene and plagioclase. Secondary minerals: chlorite, bowlingite and iddingsite which is a product of the olivine alteration in the rock (Figure 4(a)). In some crystals of augite (Figure 4(b)) and plagioclase, zoning can be observed. The second group: andesitic basalt to basaltic andesite: These rocks have microliticporphyritic to hyalooporphyritic and glomeroporphyritic texture (Figure $4(\mathrm{c})$ ). Given the diversity of rock, the major minerals of the rock include olivine, augite, plagioclase and hornblende (Figure 4(d)).

The third group: pyroxene andesite and andesite: These rocks have microliticporphyritic and sometimes glomerporphyritic texture (Figure 4(e)). The major mineral of pyroxene andesite rock include: plagioclase, amphibole, which andesites lack pyroxene mineral. Plagioclase mineral in these rock has sieve texture and zoning and burned margins (opacitic) can be seen in amphibole (Figure 4(f)), which hornblende can be observed only in some andesites.

In most investigated rocks, there are different types of xenoliths and xenocrysts (Figure 5). Xenoliths are composed of gabbro, diorite and sometimes basalt. This xenoliths
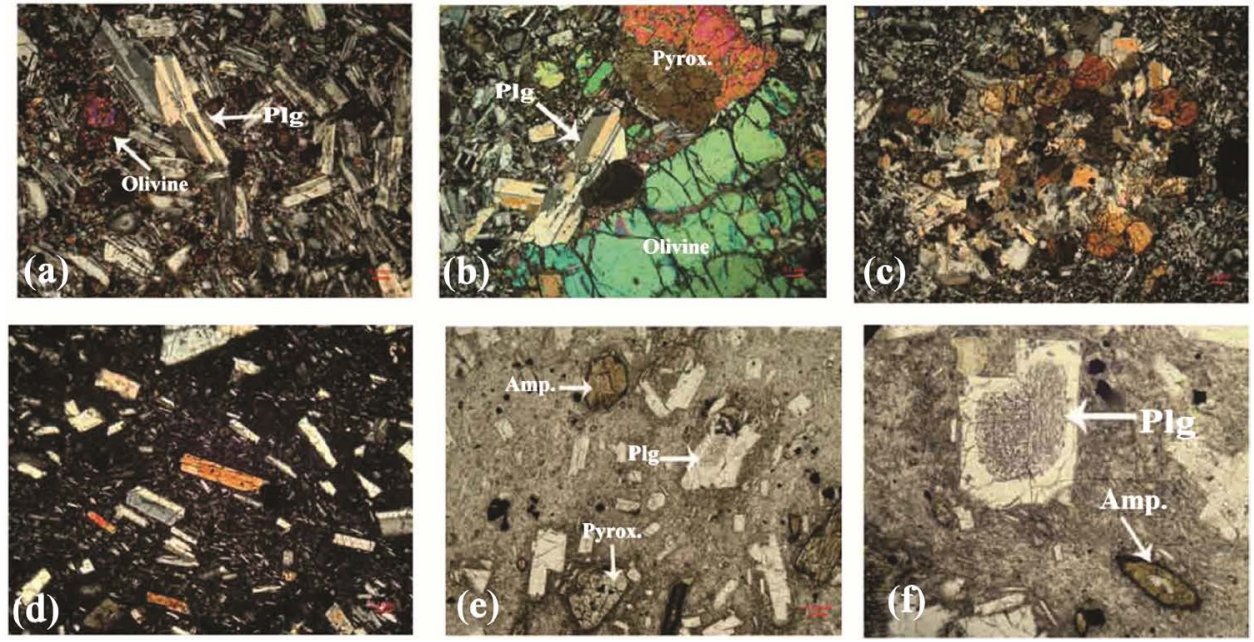

Figure 4. Microscopic images of rocks of the area with magnification $\times 40$. (a) An image of the iddingsitc olivine in olivine basalt (XPL); (b) A view of the olivine basalts and zoning of the clinopyroxene mineral (XPL); (c) A view of the glomeroporphyritic texture in basaltic andesite (XPL); (d) A view of the basaltic andesite (XPL); (e) The presence of amphibole, pyroxene and plagioclase in the pyroxene andesite rock (PPL); (f) A view of the opacitized amphibole with burned edges and plagioclase with sieve texture in the andesite rock (PPL).
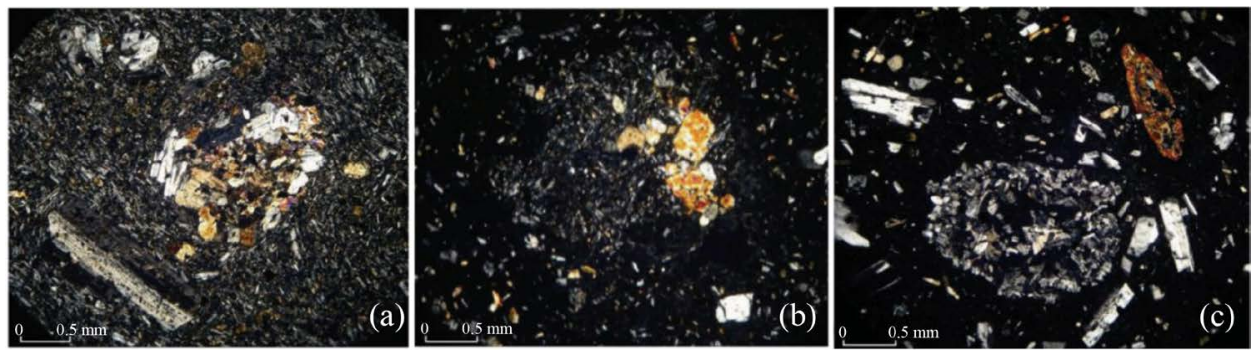

Figure 5. Xenoliths in volcanic rocks of the area. (a) Gabbroic xenoliths; (b) Dioritic xenoliths; (c) Basaltic xenoliths. 
and xenocrysts are of petrographic evidence for magmatic contamination. $\mathrm{SiO}_{2}$ content of the rocks in area is in a wide range of $45.3 \%$ to $68.1 \%$. Seven samples have a silica content of $45 \%-52 \%$, which are considered as a part of the basic rocks in the region. Also, two samples have more than $63 \%$ silica which are part of acidic rocks, and the other rocks are in the range of intermediate rocks. In the logarithmic plot of $\mathrm{Zr} / \mathrm{TiO}_{2} \mathrm{vs}$. $\mathrm{Nb} / \mathrm{Y}$ from [9], the samples show a trend of basalt, basaltic andesite and trachyandesite (Figure 6).

Reference [10], the contents of oxides $\mathrm{SiO}_{2}, \mathrm{MgO}, \mathrm{CaO}$ and $\mathrm{Fe}_{2} \mathrm{O}_{3}$ decrease and the contents of $\mathrm{Na}_{2} \mathrm{O}, \mathrm{K}_{2} \mathrm{O}$ increase with increasing silica content (Figure 7). Also, along with increasing the trend of differentiation, namely decreasing $\mathrm{MgO}$ content, the ratio of $\mathrm{CaO} / \mathrm{Al}_{2} \mathrm{O}_{3}$ regularly decreases (Figure 8). Olivine fractionation does not change the ratio of $\mathrm{CaO} / \mathrm{Al}_{2} \mathrm{O}_{3}$ and only with the use of $\mathrm{Mg}$ in its structure, reduces the content of $\mathrm{MgO}$ in the remaining melt. But, on the other hand, $\mathrm{CaO} / \mathrm{Al}_{2} \mathrm{O}_{3}$ ratio was low in plagioclase so that the content of this ratio in clinopyroxene is about tenfold of plagioclase, so the ratio of $\mathrm{CaO} / \mathrm{Al}_{2} \mathrm{O}_{3}$ decreases with the clinopyroxene fractionation [11].

On the $\mathrm{Al}_{2} \mathrm{O}_{3} / \mathrm{CaO}$ vs. $\mathrm{SiO}_{2}$ variation diagram (Figure 9), a linear positive correlation was observed between the samples and follows the vector of clinopyroxene fractionation [12]. On the other hand, along with decreasing MgO content, namely increasing differentiation, the content of $\mathrm{Al}_{2} \mathrm{O}_{3}$ remains constant that this indicates the lack of plagioclase fractionation (Figure 10). The major elements variation diagrams indicate olivine and clinopyroxene fractionation in the magma evolution trend of rocks in the area. In Figure 11, a linear positive correlation was observed between incompatible elements and interestingly passed through the coordinate origin. According to [2], constant remaining of the incompatible elements concentration is possible only as a result of fractional crystallization and from his view, this is a distinct feature found in many volcanic series of the intracontinental rift in eastern Africa. Of course, in her opinion, it should be cautious to interpret samples correlation and generated trends as the actual line of liquid descend, because these trends are also maintained in series which exposed to the

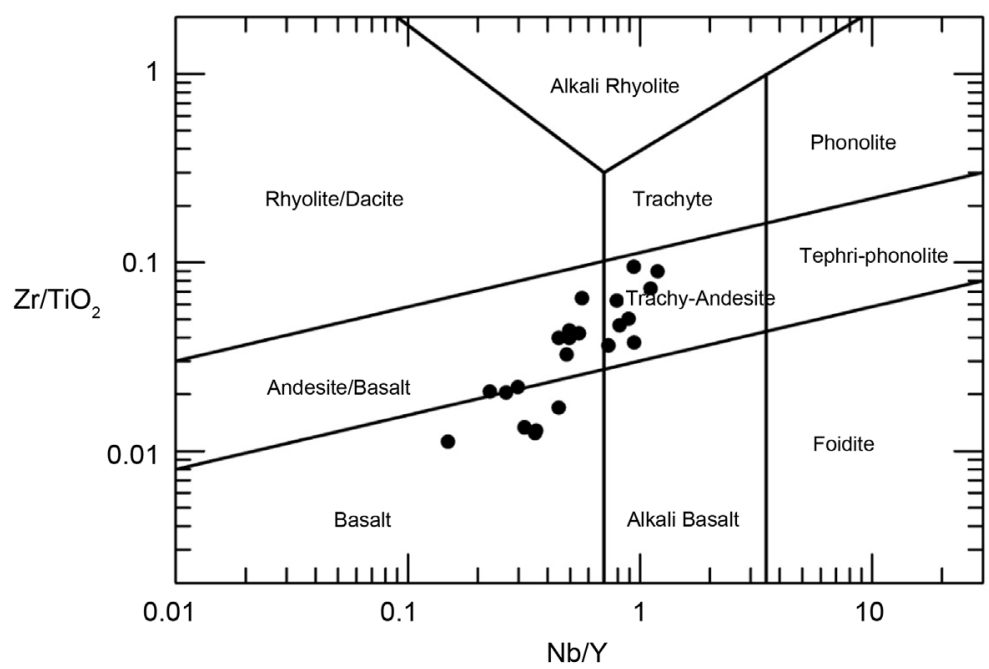

Figure 6. Position of the area rocks in logarithmic diagram $\mathrm{Zr} / \mathrm{TiO}_{2} \mathrm{vs.} \mathrm{Nb} / \mathrm{Y}$ [9]. 

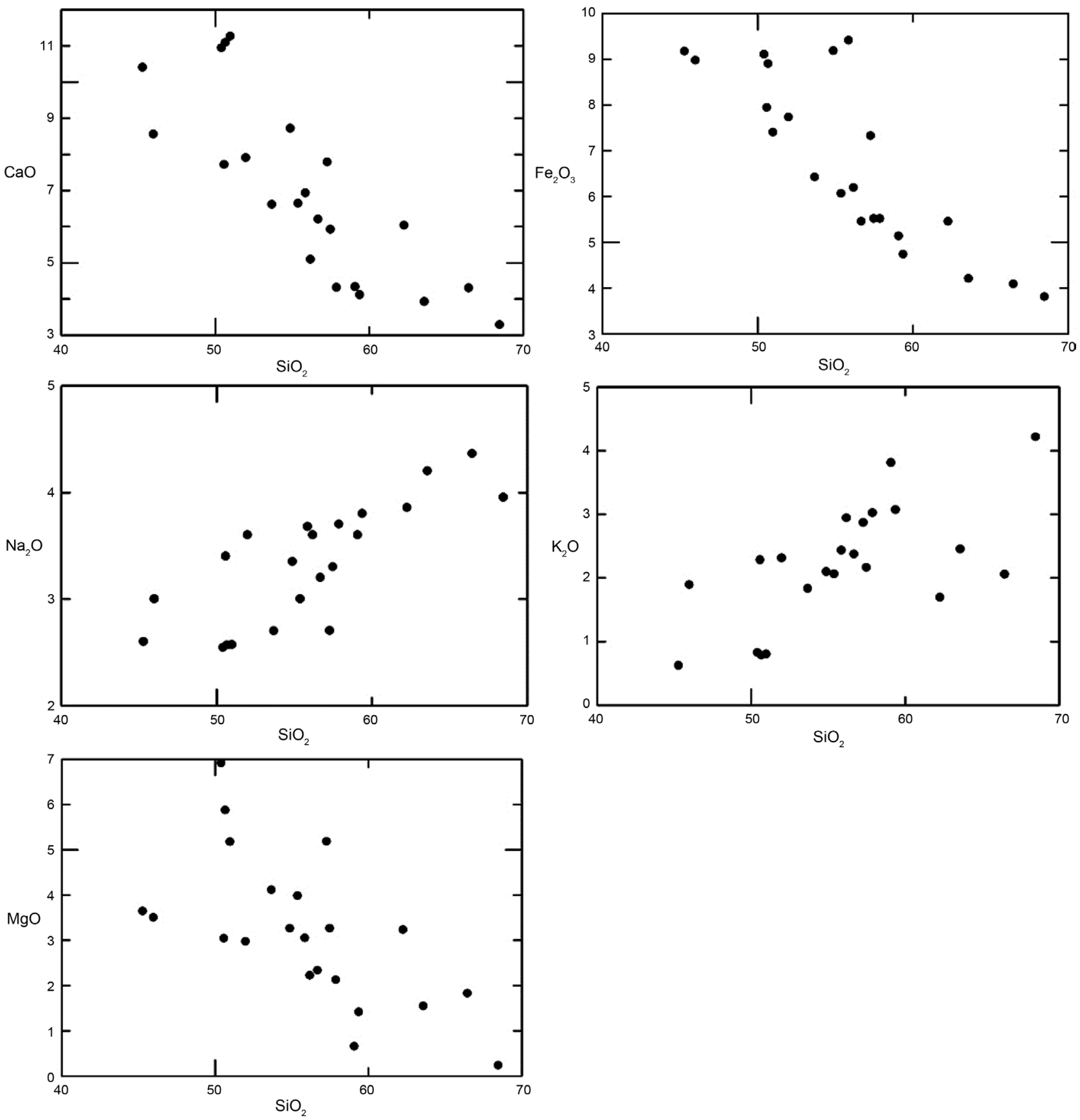

Figure 7. Variations of the main elements against the silica in the volcanic rocks of the area [10].

AFC process (assimilation with fractional crystallization).

\section{Crustal Contamination}

In petrogenesis studies of all within-plate continental provinces, it should pay attention that magmas during ascent how much interacted the continental crust rocks. Therefore, in the genesis of magmas in these regions, it should be always considered the role of crustal contamination [2]. The $\mathrm{K}_{2} \mathrm{O} / \mathrm{P}_{2} \mathrm{O}_{5}$ ratio in samples of the area is variable from 


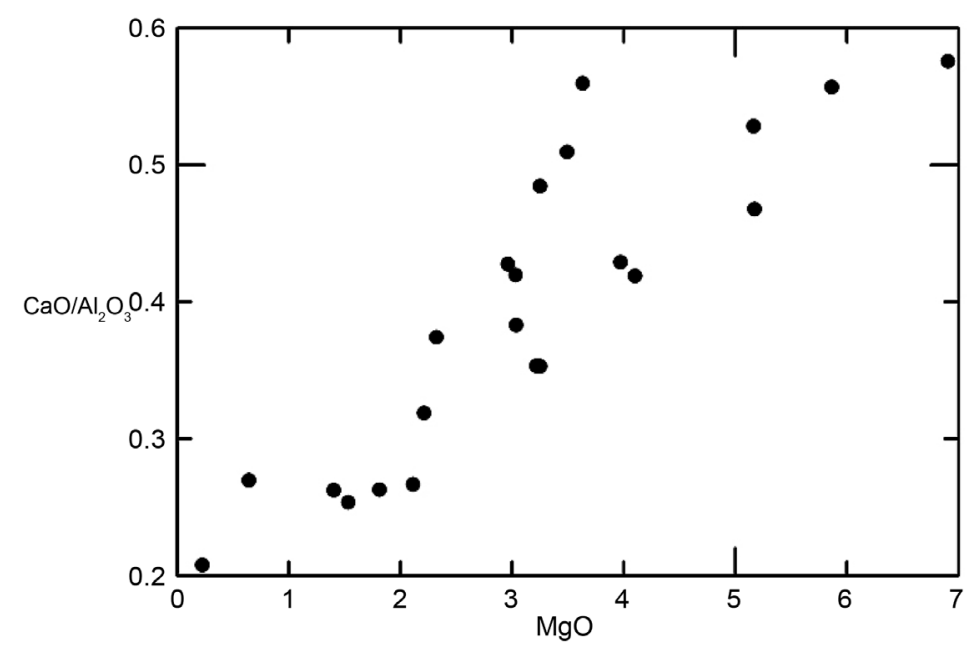

Figure 8. Variations diagram of $\mathrm{CaO} / \mathrm{Al}_{2} \mathrm{O}_{3}$ vs. $\mathrm{MgO}$ in the volcanic rocks of the area.

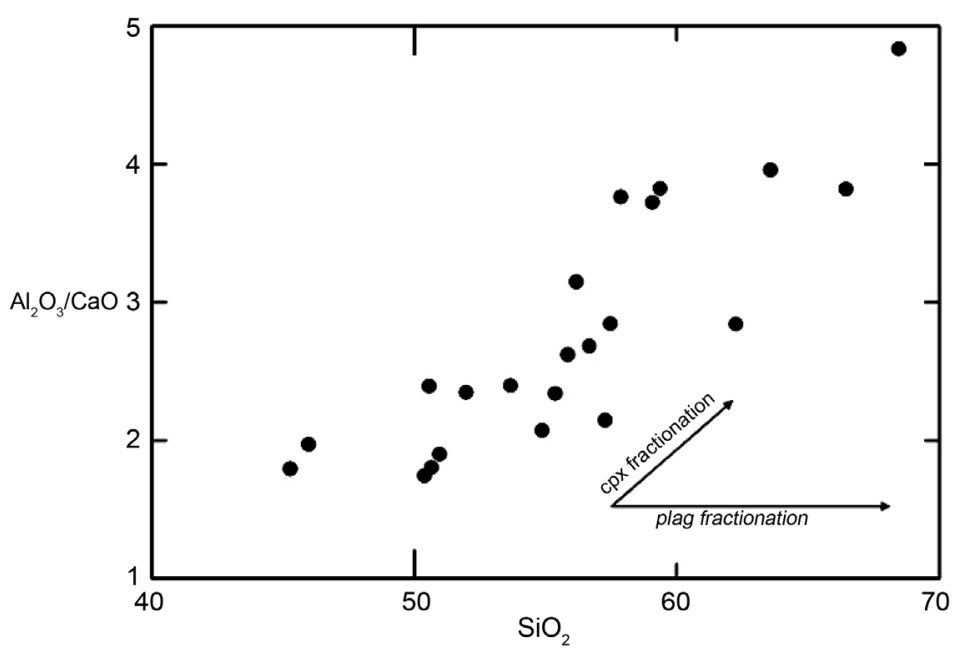

Figure 9. Variations diagram of $\mathrm{Al}_{2} \mathrm{O}_{3} / \mathrm{CaO}$ vs. $\mathrm{SiO}_{2}$ in the volcanic rocks [12].

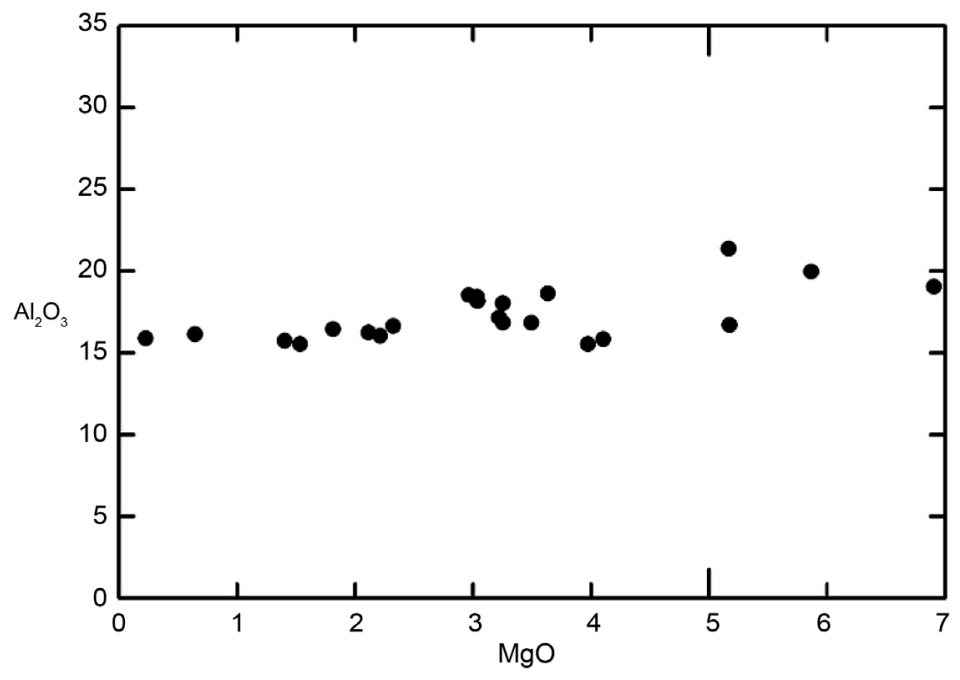

Figure 10. Variations diagram of $\mathrm{Al}_{2} \mathrm{O}_{3}$ vs. $\mathrm{MgO}$ in the volcanic rocks of the area. 
3.87 in the most acidic samples to 24 in the most basic samples. Generally, the mantle-derived basalts have the ratio of $\mathrm{K}_{2} \mathrm{O} / \mathrm{P}_{2} \mathrm{O}_{5} \leq 2$ [13]. Crustal assimilation or apatite fractionation results in increasing the mentioned ratio [13]. In Figure 12, positive correlation of $\mathrm{K}_{2} \mathrm{O} / \mathrm{P}_{2} \mathrm{O}_{5}$ against $\mathrm{SiO}_{2}$ can be seen.
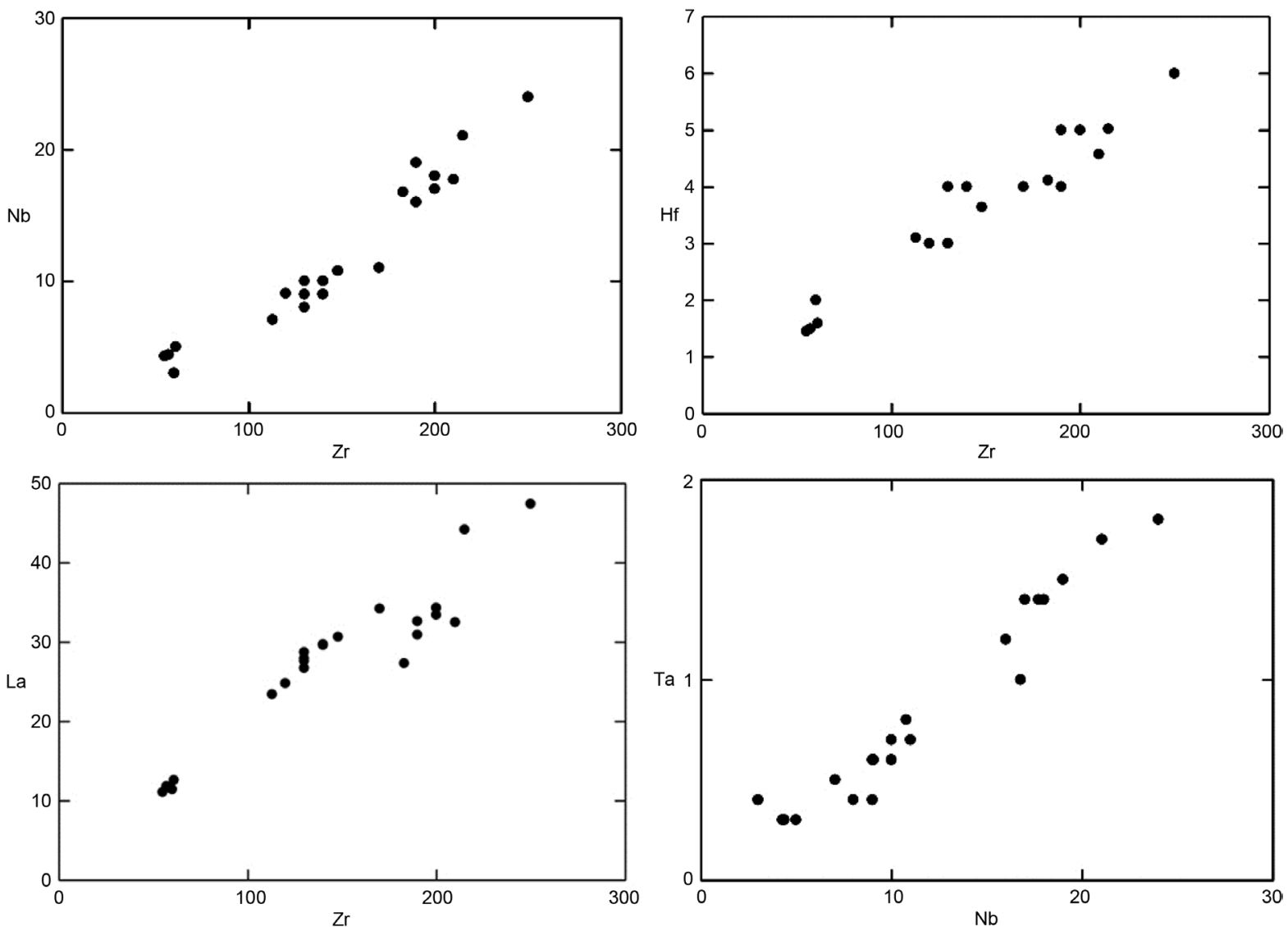

Figure 11. Variations diagram of incompatible trace elements in the volcanic rocks of the area.

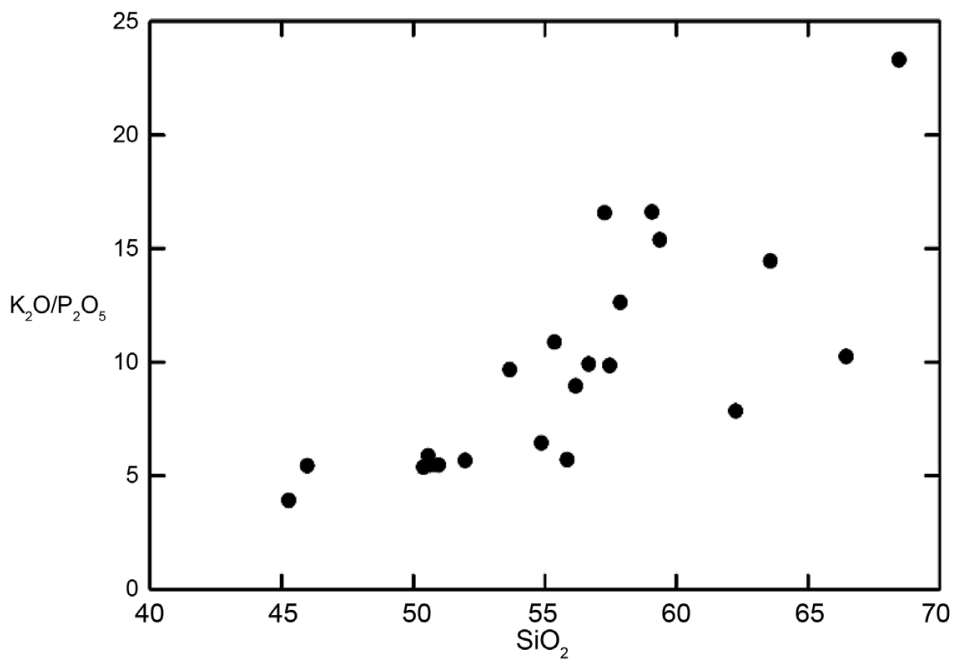

Figure 12. Variations diagram of $\mathrm{K}_{2} \mathrm{O} / \mathrm{P}_{2} \mathrm{O}_{5}$ vs. $\mathrm{SiO}_{2}$ in the volcanic rocks. 
According to [14], increasing the ratio of $\mathrm{K} / \mathrm{P}$ along with increasing $\mathrm{SiO}_{2}$ suggest crystal fractionation of mafic magma associated with silica crustal assimilation enriched in K. According to these researchers, this phenomenon has been hypothesized as the main factor of generating intermediate magmas in within-plate continental setting. The signature $\mathrm{La} / \mathrm{Sm}$ is of sensitive crustal contamination indicators, too [15]. In Figure 13, there is a linear positive correlation between the ratios of $\mathrm{La} / \mathrm{Sm}$ against $\mathrm{K}_{2} \mathrm{O} / \mathrm{P}_{2} \mathrm{O}_{5}$. The most basic sample has the lowest ratios of $\mathrm{La} / \mathrm{Sm}$ and $\mathrm{K}_{2} \mathrm{O} / \mathrm{P}_{2} \mathrm{O}_{5}$ and the most acidic sample has the highest ratios of $\mathrm{La} / \mathrm{Sm}$ and $\mathrm{K}_{2} \mathrm{O} / \mathrm{P}_{2} \mathrm{O}_{5}$.

\section{Mantle Source}

The ratios of incompatible elements in basaltic systems are used to distinguish mantle and crustal sources [3]. According to [16], the ratios of incompatible elements can act as the geochemical tracers in the source area. The binary diagram $\mathrm{Y} / \mathrm{Nb}$ vs. $\mathrm{Zr} / \mathrm{Nb}$ can be used to the effect of OIB plumes on MORB geochemistry [2]. In the $\mathrm{Y} / \mathrm{Nb} \mathrm{vs}$. $\mathrm{Zr} / \mathrm{Nb}$ diagram, the region's samples apparently place on the trend that is a melange of depleted MORB source and an enriched source (characteristic of Kenya rift or enriched source of OIB) (Figure 14). The most basic sample (N8) is close to MORB source and the samples exhibit a linear trend towards continental crust and OIB source.

According to [2], observation of this trend suggests being involved of MORB asthenospheric mantle source in petrogenesis of the rocks in the area. In the diagram of $\mathrm{Rb} / \mathrm{Y}$ vs. $\mathrm{Nb} / \mathrm{Y}$ from [17], the samples of the region from the basic to intermediate indicate the trend of a MORB source towards upper continental crust (Figure 15). Location of samples in the area is shown in the logarithmic plot of $\mathrm{Nb} / \mathrm{Y}$ vs. $\mathrm{Zr} / \mathrm{Y}$ (Figure 16). Generally, this diagram is almost insensitive to the effects of alteration processes, crystal fractionation and different degrees of partial melting [18]. According to [19], linear trends in the diagram at least purpose two different source regions in the petrogenesis of magmas. As observed, the most basic sample of the area (N8) has the lower ratios of $\mathrm{Nb} / \mathrm{Y}$ and $\mathrm{Zr} / \mathrm{Y}$, which is of characteristics of depleted sources such as MORB

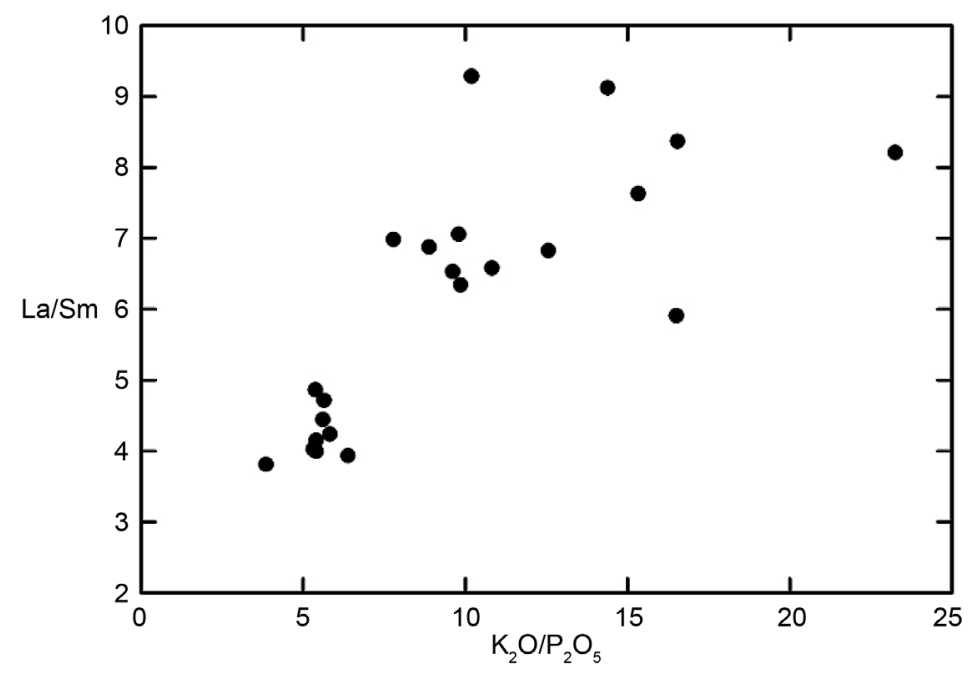

Figure 13. Variations diagram of $\mathrm{La} / \mathrm{Sm}$ vs. $\mathrm{K}_{2} \mathrm{O} / \mathrm{P}_{2} \mathrm{O}_{5}$ of the area in the volcanic rocks of the area. 


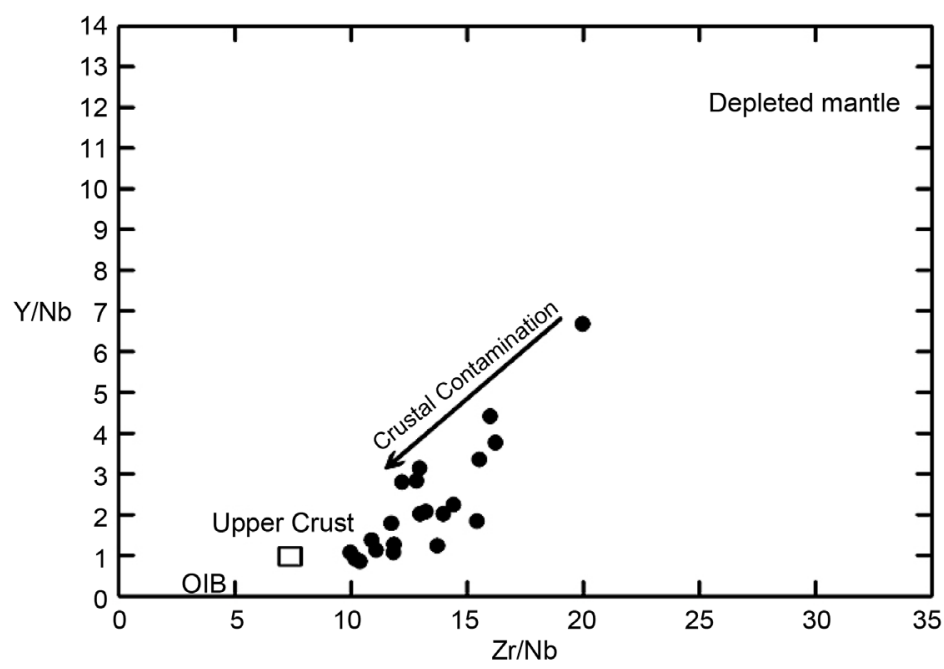

Figure 14. Position of the volcanic samples of the area in the binary plot of $\mathrm{Y} / \mathrm{Nb}$ vs. $\mathrm{Zr} / \mathrm{Nb}$.

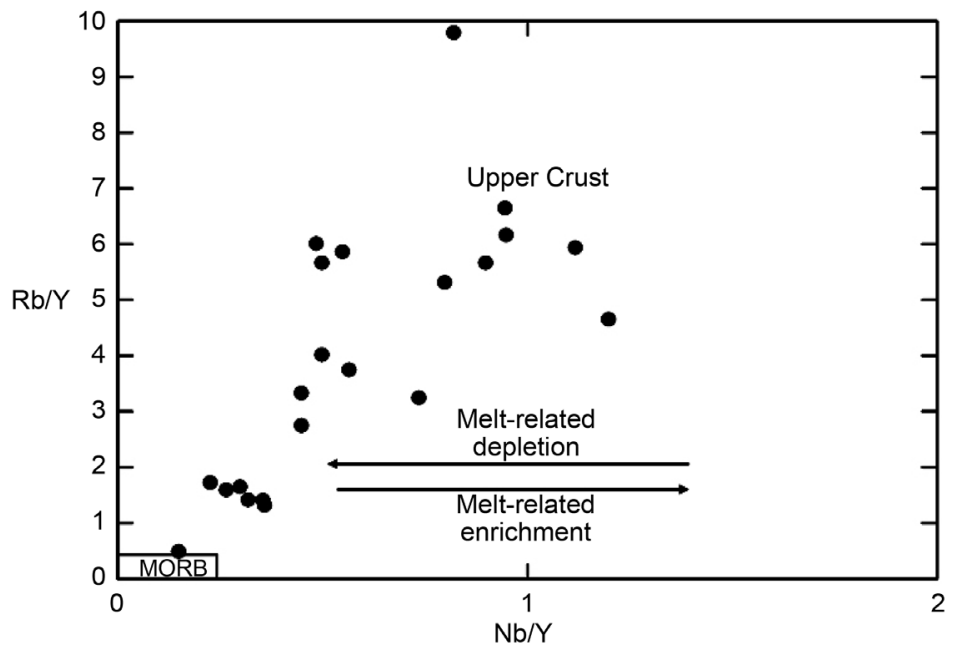

Figure 15. Position of the volcanic samples of the area binary plot of Rb/Y vs. $\mathrm{Nb} / \mathrm{Y}$ [17].

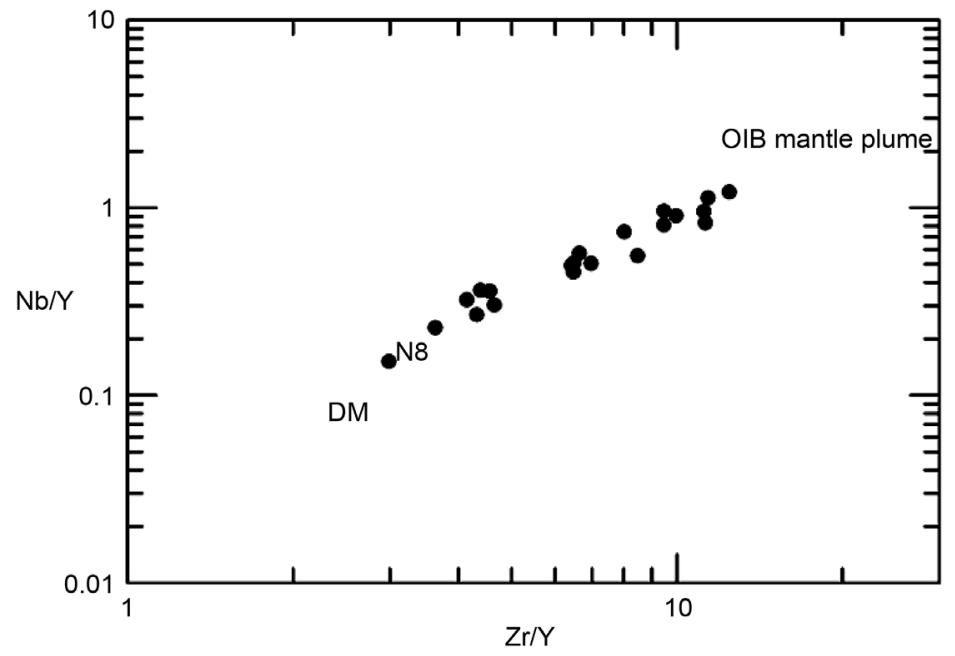

Figure 16. Position of the volcanic samples in the in the logarithmic plot of $\mathrm{Nb} / \mathrm{Y}$ vs. $\mathrm{Zr} / \mathrm{Y}$ [18]. 
source. Whereas samples gradually and linearly diverted towards the OIB mantle and exactly follow the continental crust trend. This purposes both MORB asthenospheric mantle source and continental crust involvement in the petrogenesis of volcanic rocks in the region.

\section{Conclusion}

Tertiary volcanic rocks of the study area in northern Iran, located at Alborz Mountains, represent compositional diversity between olivine basalt to andesite; based on geochemical evidence these rocks have been contaminated with the lower and upper continental crust. The presence of different xenoliths and xenocrysts in these rocks confirms this contamination. Investigations of the ratios of incompatible trace elements suggest that the basic samples of the region are close to MORB asthenospheric mantle source and the trends between primary and evolved samples indicate a linear arrangement between the MORB source mantle and the continental crust, representing an interaction of the MORB mantle-derived magmas with continental crust. In the ( $\mathrm{Tb} / \mathrm{Yb})$ $\mathrm{N}$ vs. (La/Sm) $\mathrm{N}$ diagram, all samples fall in spinel mantle in horizontal trend with an almost constant ratio of 1.28 (Figure 17 ). The contents of $(\mathrm{Tb} / \mathrm{Yb})<1.8$ are characteristics of the mantle source with spinel facies [20]. In this diagram, the most basic sample (N8) is close to the MORB source and as shown in Figure 13, the ratio of $\mathrm{La} / \mathrm{Sm}$ is strongly influenced by crustal contamination and the observed linear trend resulted from crustal contamination. In the $\mathrm{La} / \mathrm{Sm}$ vs. Sm/Yb diagram (Figure 18), the contents of partial melting of a MORB source are shown [21]. As it would be considered, samples of the area indicate constant ratios of Sm/Yb so that the most basic sample has the least amount of $\mathrm{La} / \mathrm{Sm}$ and is closer to the MORB source. Since basic samples of the area have also been contaminated with the lower crust, the primary samples before contamination possibly have lower ratios of $\mathrm{La} / \mathrm{Sm}$, and the vertical linear trend of samples shows about $15 \%$ melting of a MORB source. All geochemical evidence indicates that the volcanic rocks in the area were originated from the $15 \%$ melting of a MORB asthe-

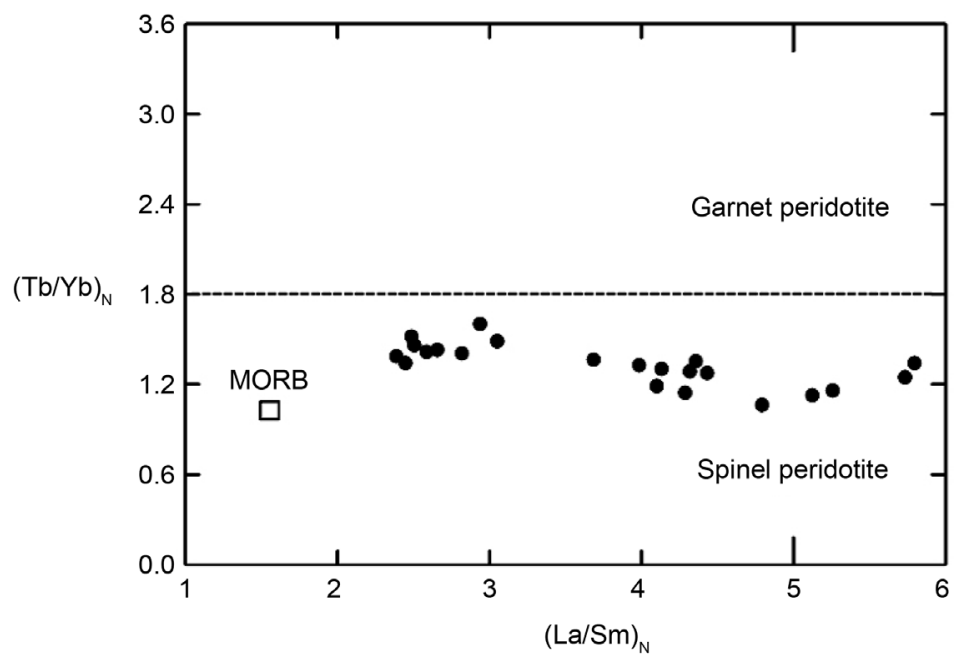

Figure 17. Position of the area's volcanic samples the diagram $(\mathrm{Tb} / \mathrm{Yb})_{\mathrm{N}} \mathrm{vs} .(\mathrm{La} / \mathrm{Sm})_{\mathrm{N}}$. 
nosphere mantle source with spinel facies, which was contaminated with the continental crust rocks to some degree. The role of MORB asthenospheric mantle is hypothesized in petrogenesis of both the mid-oceanic-ridge basalts and intra-continental rift basalts and continental flood basalts [2]. In the logarithmic plot of $\mathrm{K}_{2} \mathrm{O} / \mathrm{Yb}$ vs. $\mathrm{Ta} / \mathrm{Yb}$ from [22], the within-array mantle samples show a trend from the mantle MORB source to the mantle enriched within-plate (Figure 19). On the $\mathrm{Ba} / \mathrm{La}$ vs. La/Sm diagram of [23], location of volcanic samples in the area is shown (Figure 20). According to [23], the ratio of $\mathrm{Ba} / \mathrm{La}$ strongly depends on released fluids from the subducted slab while the $\mathrm{La} / \mathrm{Sm}$ ratio is affected by the crustal contamination. As observed in the diagram, the

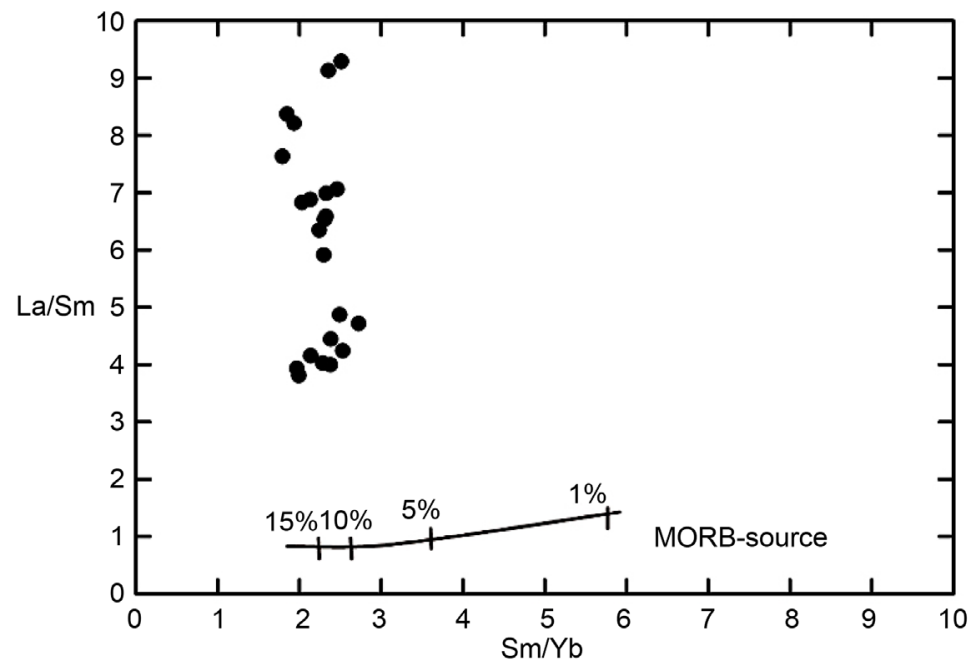

Figure 18. Position of the area's volcanic samples on the diagram La/Sm vs. Sm/Yb [21].

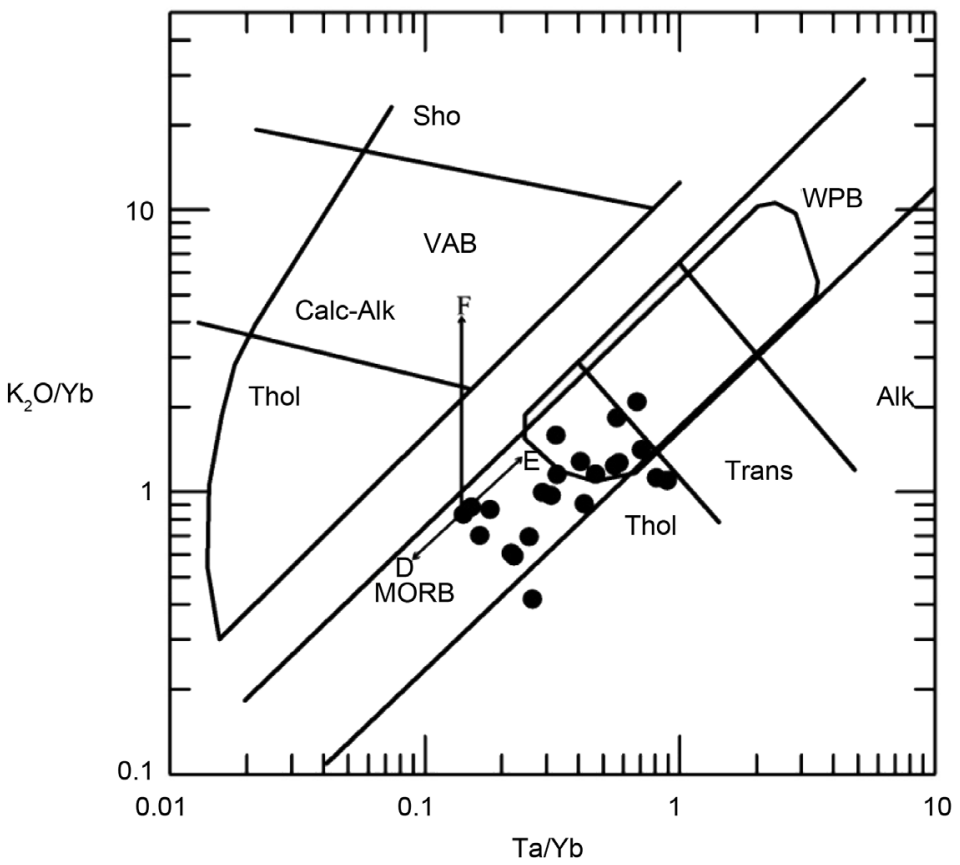

Figure 19. Position of area's rocks in the logarithmic plot of $\mathrm{K}_{2} \mathrm{O} / \mathrm{Yb}$ vs. $\mathrm{Ta} / \mathrm{Yb}$ [22]. 
samples of Nash region have the low and almost constant ratios of $\mathrm{Ba} / \mathrm{La}$, and show horizontal trend from the MORB source in the direction of crustal contamination vector. On the logarithmic diagram Th/Hf vs. Ta/Hf of [24], all the samples have fallen in the range of $I V$, namely the continental within-plate basalts and $\mathrm{IV}_{3}$ district, namely the continental extensional belts or initial rift (Figure 21). Based on the evidence of magma contamination with the continental crust, which was described in previous discussions, the association of the rocks in area with the MORB-type basalts is negative and they are possibly related to the continental within-plate environment. According to [2], the as-

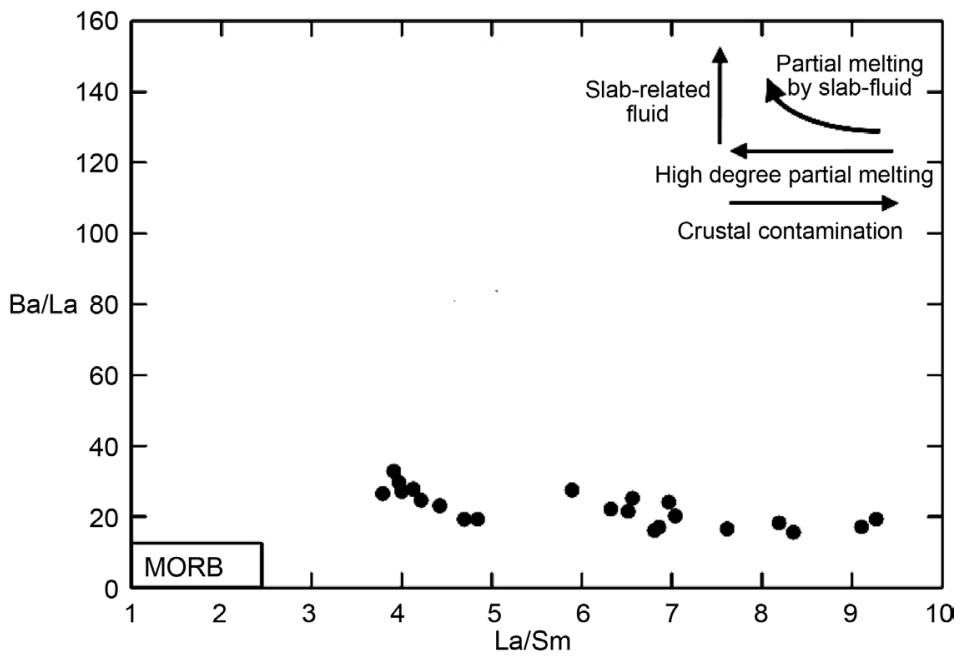

Figure 20. Position of area's rocks in the plot of $\mathrm{Ba} / \mathrm{La}$ vs. La/Sm [23].

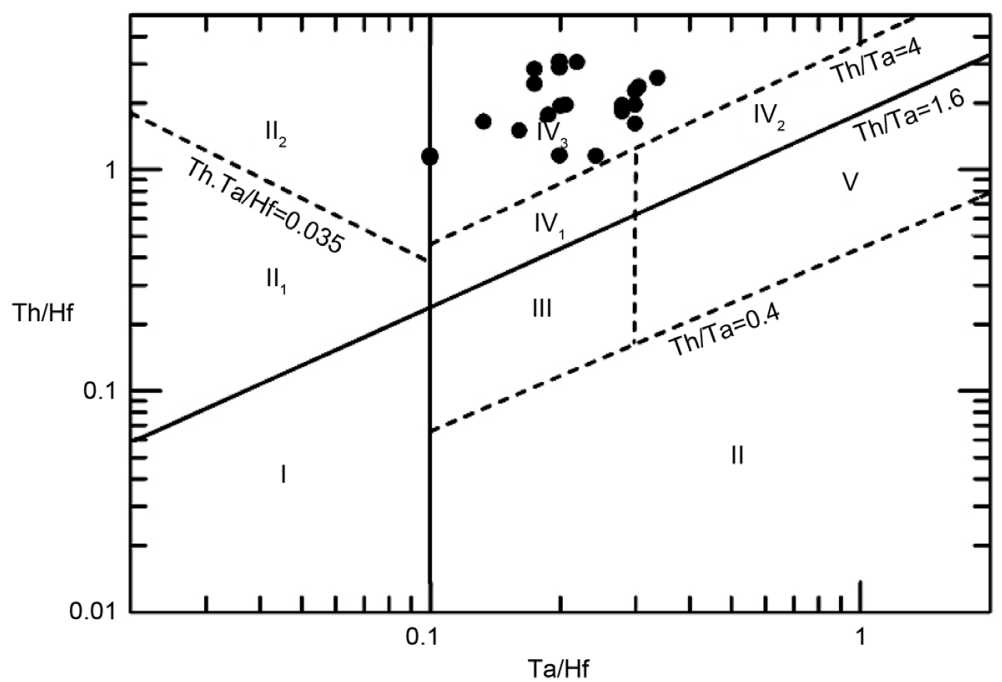

Figure 21. Logarithmic plot of Th/Hf vs. Ta/Hf adapted from [24] defined as following in the areas, $\mathrm{I}$ : MORB region type $\mathrm{N}$ in the divergent plates margin II: basalts of the convergent plates margins areas $\mathrm{II}_{1}$ : basalts of the oceanic island arc areas $\mathrm{II}_{2}$ : Basalts of the continental-margin arc volcanic regions and the continental-margin arc islands III: E-type MORB regions and basalts of the within-plate oceanic islands IV: basalts of the continental within-plate $\left[\mathrm{IV}_{1}\right.$ : the intra-continental rifts and the continental margin toleites rifts $\mathrm{IV}_{2}$ : alkali basalts of the intra-continental rift regions $\mathrm{IV}_{3}$ : basalts of the continental extensional belts or initial rift] V: basalts of the mantle plumes areas. 
thenospheric mantle MORB source plays an important role in the petrogenesis of intra-continental rifts, indicating the most active extension, and this could be seen in volcanic rocks of the Afar rift in Ethiopia, the Rio Grande in New Mexico, America and the Basin and Range province in the West America. We believe that volcanic rocks in the area were generated by $15 \%$ melting of an asthenospheric mantle MORB source with spinel facies within continental rift environment that was contaminated with continental crust rocks to some degree and underwent the AFC process.

\section{References}

[1] Jung, C. (2003) Geochemische and Isotopen-geochemische UnterSuchungen an tertiaeren valkaniten der Hocheifel-einbeitag zur identifizierung der mantelquellen von Rift-bezo genenvulkaniten. Dissetation zur Erlangung des doktorgrades Naturwissenchaften, vorgelegt dem fachbreich Geowissenschaften der Philipps-Universitaet Marburg, Deuschland.

[2] Wilson, M. (1989) Igneous Petrogenesis: A Global Tectonic Approach. Unwin Hyman, London. http://dx.doi.org/10.1007/978-1-4020-6788-4

[3] Weaver, B.L. (1991) The Origin of Ocean Island Basalt End-Member Compositions: Trace Element and Isotopic Constraints. Earth and Planetary Science Letters, 104, 381-397. http://dx.doi.org/10.1016/0012-821X(91)90217-6

[4] Rollinson, H.R. (1993) Using Geochemical Data: Evolution, Presentation, Interpretation. Longman Scientific and Technical, England.

[5] Mysen, B.O. (1982) The Role of Mantle Anatexis. In: Thorpe, R.S., Ed., Andesites, Wiley, Chichester, New York, 489-522.

[6] Ellam, R.M. (1992) Lithospheric Thickness as a Control on Basalt Geochemistry. Geology, 20, 153-156. http://dx.doi.org/10.1130/0091-7613(1992)020<0153:LTAACO >2.3.CO;2

[7] Stocklin, J. (1968) Structural History and Tectonic of Iran: A Review. American Association of Petroleum Geologists Bulletin, USA, 52, 1229-1258.

[8] Ghalamghash, J. (2001) Geological Map of Jirandeh 1:100000. Geological Survey of Iran, Tehran.

[9] Winchester, J.A. and Floyd, P.A. (1977) Geochemical Discrimination of Different Magma Series and Their Differentiation Product Using Immobile Elements. Chemical Geology, 20, 325-343. http://dx.doi.org/10.1016/0009-2541(77)90057-2

[10] Harker, A. (1909) The Natural History of Igneous Rocks. Methuen, London.

[11] Le Roux, P.J. (2002) Crystallization Processes beneath the Southern Mid-Atlantic Ridge (40 - $55^{\circ} \mathrm{S}$ ), Evidence for High-Pressure Initiation of Crystallization. Contributions to Mineralogy and Petrology, 45, 318-332. http://dx.doi.org/10.1007/s00410-001-0312-y

[12] Zhu, D.C., Pan, G.T., Mo, X.X., Liao, Z.L., Jiang, X.S., Wang, L.Q. and Zhao, Z.D. (2007) Petrogenesis of Volcanic Rocks in the Sangxiu Formation, Central Segment of Tethyan Himalaya: A Probable Example of Plume-Litospher Interaction. Journal of Asian Earth Sciences, 29, 320-335. http://dx.doi.org/10.1016/j.jseaes.2005.12.004

[13] Carlson, R.W. and Hart, W.K. (1988) Flood Basalt Volcanism in the Northwestern United States. In: McDougal, J.D., Ed., Continental Basalt, Kluwer Academic Publishers, Durdrecht, Netherland, 273-310. http://dx.doi.org/10.1007/978-94-015-7805-9 2

[14] Brueseke, M.E. and Hart, W.K. (2009) Intermediate Composition Magma Production in an Intracontinental Setting: Unusual Andesites and Dacites of the Mid-Miocene Santa Rosa-Calico Volcanic Field, Northern Nevada. Journal of volcanology and Geothermal Research, 188, 197-213. http://dx.doi.org/10.1016/j.jvolgeores.2008.12.015 
[15] Lightfoot, P.C. and Keays, R.R. (2005) Siderophile and Chalcophile Metal Variations in Tertiary Picrites and Basalts from West Greenland with Implications for the Sulphide Saturation History of Continental Flood Basalt Magmas. Economic Geology, 100, 439-462. http://dx.doi.org/10.2113/gsecongeo.100.3.439

[16] Hoffman, A.M. (1997) Mantle Geochemistry: The Messages from Oceanic Volcanism. Nature, 385, 219-229. http://dx.doi.org/10.1038/385219a0

[17] Zhao, J.H. and Zhou, M.F. (2007) Geochemistry of Neoproterozoic Mafic Introsions in the Panzhihua District (Sichuan Province, SW China): Implication for Subduction Related Metasomatism in the Upper Mantle. Precambrian Research, 152, 27-47. http://dx.doi.org/10.1016/j.precamres.2006.09.002

[18] Fitton, J.G., Saunders, A.D., Norry, M.J., Hardarson, B.S. and Taylor, R.N. (1997) Thermal and Chemical Structure of the Iceland Plume. Earth and Planetary Science Letters, 153, 197-208. http://dx.doi.org/10.1016/S0012-821X(97)00170-2

[19] Wilson, M. and Lyashkevich, Z.M. (1996) Magmatism and the Geodynamics of Rifting of the Pripyat-Dnieper-Donetsrift, East European Platform. Tectonophysics, 268, 65-81.

http://dx.doi.org/10.1016/S0040-1951(96)00234-X

[20] Wang, K., Plank, T., Walker, J.D. and Smith, E.I. (2002) A Mantle Melting Profile across the Basin \& Range, SW USA. Journal of Geophysical Research, 107, ECV 5-1-ECV 5-21. http://dx.doi.org/10.1029/2001jb000209

[21] Kuepouo, G., Tchouankoue, J.P., Nagao, T. and Sato, H. (2006) Transitional Tholeiitic Basalts in the Tertiary Bana Volcano-Plutonic Complex, Cameroon Line. Journal of African Earth, 45, 318-332. http://dx.doi.org/10.1016/j.jafrearsci.2006.03.005

[22] Pearce, J.A. (1982) Trace Element Characteristics of Lavas from Destructive Plate Boundaries. In: Thorpe, R.S., Ed., Andesites, Wiley, Hoboken, 528-548.

[23] Ryan, J., Morris, J., Bebout, G. and Leeman, B. (1996) Describing Chemical Fluxes in Subduction Zones: Insights from "Depth-Profiling" Studies of Arc and Forearc Rocks. In: Bebout, G.E., Scholl, D.W., Kirby, S.H. and Platt, J.P., Eds., Subduction Top to Bottom, American Geophysical Union, Washington DC, 263-268.

[24] Wang, Y., Zhang, C. and Xia, S. (2001) Th/Hf-Ta/Hf Identification of Tectonic Setting of Basalts. Acta Petrologica Sinica, 17, 413-421. (In Chinese with English Abstract)

\section{Submit or recommend next manuscript to SCIRP and we will provide best service for you:}

Accepting pre-submission inquiries through Email, Facebook, LinkedIn, Twitter, etc.

A wide selection of journals (inclusive of 9 subjects, more than 200 journals)

Providing 24-hour high-quality service

User-friendly online submission system

Fair and swift peer-review system

Efficient typesetting and proofreading procedure

Display of the result of downloads and visits, as well as the number of cited articles

Maximum dissemination of your research work

Submit your manuscript at: http://papersubmission.scirp.org/

Or contact ojg@scirp.org 